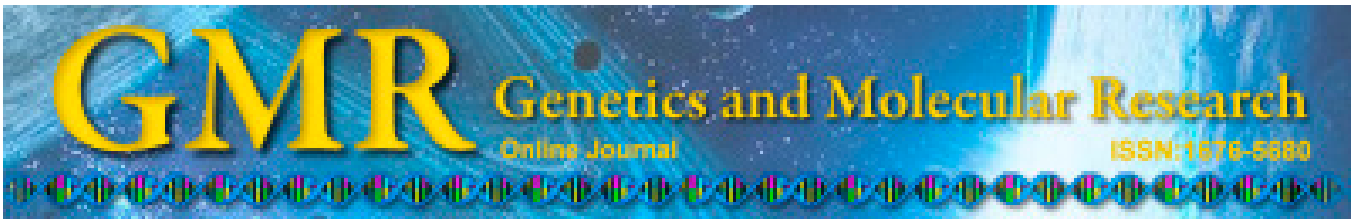

\title{
Genetic potential of common bean progenies selected for crude fiber content obtained through different breeding methods
}

V.A.P. Júnior ${ }^{1}$, P.G.S. Melo ${ }^{1}$, H.S. Pereira ${ }^{2}$, P.Z. Bassinello ${ }^{2}$ and L.C. Melo ${ }^{2}$

${ }^{1}$ Escola de Agronomia e Engenharia dos Alimentos, Universidade Federal de Goiás, Goiânia, GO, Brasil

${ }^{2}$ Embrapa Arroz e Feijão, Santo Antônio de Goiás, GO, Brasil

Corresponding author: L.C. Melo

E-mail: leonardo.melo@embrapa.br

Genet. Mol. Res. 14 (2): 5763-5774 (2015)

Received July 10, 2014

Accepted November 17, 2014

Published May 29, 2015

DOI http://dx.doi.org/10.4238/2015.May.29.8

\begin{abstract}
Gastrointestinal health is of great importance due to the increasing consumption of functional foods, especially those concerning diets rich in fiber content. The common bean has been valorized as a nutritious food due to its appreciable fiber content and the fact that it is consumed in many countries. The current study aimed to evaluate and compare the genetic potential of common bean progenies of the carioca group, developed through different breeding methods, for crude fiber content. The progenies originated through hybridization of two advanced strains, CNFC 7812 and CNFC 7829, up to the $\mathrm{F}_{7}$ generation using three breeding methods: bulk-population, bulk within $\mathrm{F}_{2}$ families, and single seed descent. Fifteen $\mathrm{F}_{8}$ progenies were evaluated in each method, as well as two check cultivars and both parents, using a $7 \times 7$ simple lattice design, with experimental plots comprised of two 4-m long rows. Field trials were conducted in eleven environments encompassing four Brazilian states and three different sowing times during 2009 and 2010. Estimates of genetic parameters indicate differences among the breeding methods, which seem to be related to the dif-
\end{abstract}


ferent processes for sampling the advanced progenies inherent to each method, given that the trait in question is not subject to natural selection. Variability amongst progenies occurred within the three breeding methods and there was also a significant effect of environment on the progeny for all methods. Progenies developed by bulk-population attained the highest estimates of genetic parameters, had less interaction with the environment, and greater variability.

Key words: Phaseolus vulgaris L.; Heritability; Genetic variance; Genotype by environment interaction

\section{INTRODUCTION}

The common bean (Phaseolus vulgaris L.) forms part of the daily diet of millions of people across the world, especially within low income populations. The common bean performs important functions in human nutrition due to its high crude fiber content ( 3 to $6 \%$ ) (Antunes et al., 1995; Ribeiro et al., 2005), and also its protein (20\%), carbohydrate (61.2\%), lipid (1.3\%), and sodium (0 to $0.05 \%$ ) content, and its lack of cholesterol (TACO, 2011).

The consumption of food rich in digestible fiber is fundamental for maintaining health and in preventing several chronic and degenerative non-transmissible diseases, such as cancer, cardiovascular problems, constipation, and obesity (Hughes, 1991; Geil and Anderson, 1994; Moore et al., 1998; Costa, 2003). Consumers present a steady awareness of their food choices, selecting functional and nutritional sources that have health benefits. According to Bach et al. (2012), for many years significant investment was injected into campaigns regarding heart health, but in more recent years, gastrointestinal health has assumed a strong research position due to the consumer's interest, favoring the dissemination of information on fiber consumption in the human diet.

Total food fiber can be divided into different fractions that have different physiological roles in the human body and may be classified based on their solubility, into soluble and insoluble fiber. The former fraction is composed of pectin substances, gums, soluble hemicellulose, $\beta$-glucanes, mucilage, and exudates, whereas the latter is composed of cellulose, lignin, and the majority of hemicelluloses and pectin substances (Hilton et al., 1983; Larbier and Leclercq, 1992; Guerra et al., 2004).

There are several biochemical and enzymatic pathways that impart the production of fiber components and each genetic combination may respond in a unique manner to a specific environmental condition (Bach et al., 2012). According to Londero et al. (2009), common beans present the highest fiber content when compared to other cereals (such as rice, maize, and wheat) and to several horticultural crops (Acevedo and Bressani, 1990). Common bean grains are comprised of three parts insoluble fiber to one part soluble fiber (Londero et al., 2006), which is an adequate proportion to be administered in the human diet (Kathleen, 1998).

Crude fiber forms part of the insoluble fraction of total edible fiber and according to literature reports these are positively correlated (Londero et al., 2006). Thus, due to this correlation, selection of common bean genotypes with a high insoluble fiber content results in a concomitant increase in the total edible fiber, making this an effective selection for the trait.

Some common bean breeding programs have aimed to develop more stable cultivars with increasingly higher yields and other traits of interest, such as grain crude fiber content. In order to achieve these aims, genetic variability must be present, in addition to the use of ef- 
ficient strategies to detect differences amongst elite genotypes. The factors that have the most effect on the efficiency of the selection process are the occurrence of genotype by environment interaction and the choice of an adequate method for developing the segregant populations (Raposo et al., 2000; Chaves, 2001).

Genotype by environment interaction has been frequently reported in common beans in association with the trait of grain yield (Ramalho et al., 1998; Carbonell et al., 2004; Oliveira et al., 2006; Melo et al., 2007; Pereira et al., 2009, 2010; Torga et al., 2013), although it has been less explored for other traits, such as crude fiber content. There are some research results, such as those by Londero et al. (2006) and Silva et al. (2013) that provide evidence that fiber content in common beans is influenced by the environment. In this sense, it is of paramount importance to determine the magnitude of the genotype by environment interaction in the estimates of the genetic parameters related to crude fiber content so that the selection of superior lines can be more efficient.

The development of segregant populations is considered the most troublesome, expensive, and critical stage of breeding autogamous species. Many methods [bulk-population, bulk within $\mathrm{F}_{2}$, pedigree, and single seed descent (SSD)] have been utilized in the breeding of these species (Vieira et al., 2005). The choice of a particular method must take into consideration the trait under selection, the maintenance of variability throughout the generations, the number of elite progenies generated, and the sampling effects. The methods have been frequently compared in several crops, mainly for the trait of grain yield. For common beans, besides yield (Raposo et al., 2000), protein content was studied by Silva et al. (2008) and fiber content by Silva (2009). In these cases, estimates of genetic parameters were utilized to aid in the comparison of the potential of selected progenies through different methods. For grain yield, the methods of bulk-population and SSD were the most advantageous, whereas for protein content, the bulk-population method was the best, and for crude fiber, both bulkpopulation and bulk within $\mathrm{F}_{2}$ were considered the most suitable.

The objectives of the present research were to evaluate and to compare the genetic potential of progenies selected using three breeding methods (bulk-population, bulk within $\mathrm{F}_{2}$, and SSD) for the crude fiber trait in common beans cultivated in several environments.

\section{MATERIAL AND METHODS}

Common bean progenies were obtained from crosses between two elite strains (CNFC 7812 and CNFC 7829), contrasted for insoluble fiber content, of the carioca tegument group, and developed by the breeding program of Embrapa Arroz e Feijão. Progenies were developed using three breeding methods: bulk-population ( 1000 plants per generation up to $\mathrm{F}_{5}$, with random selection of 100 plants at the last generation); modified bulk or bulk within $\mathrm{F}_{2}$ families (100 progenies per generation up to $\mathrm{F}_{5}$ ); and SSD (100 seeds per generation up to $\mathrm{F}_{5}$ ). The development of the segregant populations was performed in accordance with the description of Ramalho et al. (2001), later adopted by Ramalho et al. (2012). From generation $\mathrm{F}_{5}$ onwards, 64 progenies were randomly taken for each method following seed increase in generations $\mathrm{F}_{6}$ and $\mathrm{F}_{7}$.

The present study was undertaken using fifteen random $\mathrm{F}_{8}$ progenies originating from each breeding method (generation $\mathrm{F}_{5: 8}$ for progenies derived through bulk-population, $\mathrm{F}_{2: 8}$ for bulk within $\mathrm{F}_{2}$, and $\mathrm{F}_{5: 8}$ for SSD). A simple 7 x 7 lattice experimental design was used with plots comprised of 4-m long rows, spaced $0.5 \mathrm{~m}$ apart, and seeded at the rate of $15 \mathrm{seeds} / \mathrm{m}$. Two check cultivars were utilized (BRS Estilo and Perola) and the two original parents, totaling 49 treatments. The field trials were evaluated in different locations, months, and years of planting 
in the Brazilian states of Paraná, Minas Gerais, Goiás, and Pernambuco, for a total of eleven environments. The testing locations were Ponta Grossa, $\mathrm{PR}\left(25^{\circ} 13^{\prime} \mathrm{S}, 50^{\circ} 01^{\prime} \mathrm{W}, 880 \mathrm{~m}\right.$ in altitude), Lavras, MG $\left(21^{\circ} 22^{\prime} \mathrm{S}, 44^{\circ} 97^{\prime} \mathrm{W}, 960 \mathrm{~m}\right.$ in altitude), Sete Lagoas, MG $\left(19^{\circ} 47^{\prime} \mathrm{S}, 44^{\circ} 25^{\prime} \mathrm{W}, 732 \mathrm{~m}\right.$ in altitude), Anápolis, GO (16 $37^{\circ} \mathrm{S}, 48^{\circ} 94^{\prime} \mathrm{W}, 1017 \mathrm{~m}$ in altitude), Santo Antônio de Goiás, GO $\left(16^{\circ} 50^{\prime} \mathrm{S}, 49^{\circ} 30^{\prime} \mathrm{W}, 741 \mathrm{~m}\right.$ in altitude), and Petrolina, $\mathrm{PE}\left(9^{\circ} 15^{\prime} \mathrm{S}, 40^{\circ} 37^{\prime} \mathrm{W}, 366 \mathrm{~m}\right.$ in altitude).

Crude fiber evaluations were performed in samples taken from two replications of each of the eleven field trials. Eighty seeds were utilized in each sample, selected by size and uniform appearance (with 13\% humidity), which were then ground in an IKA A11 basic analytical mill to raw bean flour (particles smaller than $1 \mathrm{~mm}$ ).

The modifications to the method described by AOAC (1997) in the present article consisted of extracting crude fiber using the Tecnal ${ }^{\circledR}$ model TE-149 that originally determines fiber content in neutral as well as in acid detergent, which makes it possible to reduce costs and to improve the efficiency of the analysis as 27 samples can be extracted simultaneously.

Individual analyses of variance were performed for crude fiber content of progenies in each of the eleven environments. The variance components and genotypic and phenotypic parameters were estimated through the mathematical expectations of the mean squares (Vencovsky and Barriga, 1992).

Homogeneity of variance of the field trials was evaluated in accordance with the criterion suggested by Pimentel-Gomes (1990). The model concerning the combined analysis assumed the environment effect as a fixed factor and the progeny effect as a random factor (Vencovsky and Barriga, 1992). The progeny effect was partitioned into progeny within each breeding method, thus estimating the variance components and the respective estimates of the genotypic and phenotypic parameters. The expected gain of selection, as percent, of the five progenies with the highest fiber content for each breeding method was also estimated (Ramalho et al., 1993).

The error associated with the average heritability estimates of the progenies obtained using the breeding methods was determined according to Vello and Vencovsky (1974). The ratio between the estimates of the genotype by environment interaction and the genetic variance was estimated using the following equation:

$$
R_{i}=\left(\frac{\hat{\sigma}_{g x e_{i}}^{2}}{\hat{\sigma}_{g_{i}}^{2}}\right) * 100
$$

where, $R_{i}$ is the ratio of the interaction of the $i^{\text {th }} \operatorname{method}(i=1,2,3) ; \hat{\sigma}_{g x e_{i}}^{2}$ is the genotype by environment interaction of the $i^{\text {th }}$ method $(i=1,2,3)$; and $\hat{\sigma}_{g_{i}}^{2}$ is the genetic variance of the $i^{\text {th }}$ method $(i=1,2,3)$.

The relationship (as percent) between the ratio of the interaction for each method and the sum of ratios of all methods was obtained using the following equation:

$$
P_{i}=\left(\frac{R_{i}}{R_{1}+R_{2}+R_{3}}\right) * 100
$$

where, $P_{i}$ is the proportion of the interaction of the $i^{\text {th }}$ method $(i=1,2,3)$; and $R_{i}$ is the ratio of the interaction of the $i^{\text {th }}$ method $(i=1,2,3)$. 
To compare the methods used for developing the segregant populations based on mean fiber content, $10 \%$ of the total number of progenies under evaluation was selected. Thus, for each method, the five best $\left(P_{5_{+}}\right)$and the five worst $\left(P_{5_{-}}\right)$progenies averaged over all evaluations were obtained. The number of superior progenies, in relation to parental averages, and the number of progenies surpassing the average of the highest parent for each method were also obtained. In order to compare the mean performance of the progenies, progenies were classified in descending order for crude fiber content and the total sum of all ranks (TSR) was obtained for each method, so that the method with the smallest TSR was considered the one with to be the highest potential to generate superior progenies.

\section{RESULTS AND DISCUSSION}

The individual analyses of the field tests in the eleven environments showed significant differences among genotypes $(\mathrm{P}<0.05)$ for the majority of the experiments $(91 \%)$, indicating variability among progenies, parents, and check cultivars. The values of the experimental coefficients of variation were all small $(<7 \%)$, thus indicating adequate experimental precision in the evaluations of crude fiber content.

The average crude fiber content across environments varied from 4.56 to $5.27 \%$, which represents a $15.5 \%$ increase in relation to the smallest average, thus indicating the presence of environmental variation (Table 1). Such variation also occurred amongst the average of the parents, with extreme genotypes having approximately $17.7 \%$ greater average crude fiber content, and in almost all environments the parental average was smaller than the overall mean. From observing the geographic data for the locations of the field tests, variation in altitude (from $366 \mathrm{~m}$ to $1017 \mathrm{~m}$ ), latitude (from $9^{\circ} 15^{\prime} \mathrm{S}$ to $25^{\circ} 13^{\prime} \mathrm{S}$ ) and longitude (from $40^{\circ} 37^{\prime} \mathrm{W}$ to $50^{\circ} 01^{\prime} \mathrm{W}$ ) exists, which explains the differential response of the genotypes to the environments.

Table 1. Summary of individual analysis of variance for the eleven environments and estimates of the genetic parameters for crude fiber content $(\%)$ evaluated in common bean progenies.

\begin{tabular}{|c|c|c|c|c|c|c|c|c|c|c|c|}
\hline Location & $\begin{array}{l}\text { Month/year } \\
\text { of planting }\end{array}$ & $M S_{\text {Erro }}$ & $M S_{\text {Treat }}$ & $P$ value & $\begin{array}{l}\text { Overall } \\
\text { average }\end{array}$ & $\begin{array}{c}\text { Parental } \\
\text { mean }\end{array}$ & $\hat{\sigma}_{g}^{2}$ & $\hat{\sigma}_{p}^{2}$ & $\widehat{h}^{2}(\%)$ & $C V_{g}(\%)$ & $C V_{\theta}(\%)$ \\
\hline Anápolis-GO & December/2009 & 0.0455 & 0.0781 & 0.0468 & 4.57 & 4.43 & 0.0163 & 0.0390 & 41.75 & 2.79 & 4.66 \\
\hline Ponta Grossa-PR & November/2009 & 0.0744 & 0.1499 & 0.0153 & 4.57 & 4.36 & 0.0377 & 0.0749 & 50.38 & 4.24 & 5.96 \\
\hline Anápolis-GO & June/2010 & 0.1212 & 0.6999 & 0.0000 & 5.27 & 4.40 & 0.2893 & 0.3499 & 82.69 & 10.20 & 6.60 \\
\hline Sto. A. de Goiás-GO & June/2010 & 0.0913 & 0.3744 & 0.0000 & 4.88 & 4.90 & 0.1425 & 0.1872 & 75.61 & 7.71 & 6.19 \\
\hline Sto. A. de Goiás-GO & February/2010 & 0.1077 & 0.5520 & 0.0000 & 5.19 & 5.05 & 0.2221 & 0.2760 & 80.49 & 9.07 & 6.32 \\
\hline Sto. A. de Goiás-GO & December $/ 2010$ & 0.0839 & 0.1442 & 0.0465 & 5.23 & 4.99 & 0.0301 & 0.0721 & 41.81 & 3.31 & 5.53 \\
\hline Ponta Grossa-PR & January/2010 & 0.0987 & 0.2446 & 0.0028 & 4.56 & 4.29 & 0.0729 & 0.1223 & 59.67 & 5.92 & 6.89 \\
\hline Ponta Grossa-PR & November/2010 & 0.0946 & 0.1966 & 0.0121 & 4.82 & 4.70 & 0.0510 & 0.0983 & 51.87 & 4.68 & 6.38 \\
\hline Lavras-MG & February/2010 & 0.1213 & 0.1948 & 0.0706 & 4.73 & 4.74 & - & - & - & - & - \\
\hline Sete Lagoas-MG & February/2010 & 0.0932 & 0.2886 & 0.0003 & 4.88 & 4.62 & 0.0977 & 0.1443 & 67.77 & 6.40 & 6.25 \\
\hline Petrolina-PE & April/2010 & 0.0963 & 0.2594 & 0.0013 & 4.64 & 4.33 & 0.0815 & 0.1297 & 62.86 & 6.16 & 6.69 \\
\hline
\end{tabular}

Heritability $\left(h^{2}\right)$, an estimate of the proportion of the total variation that is due to genetic factors, varied from 41.75 to $82.69 \%$. Such values are considered medium to high and indicate the possibility of success for the selection of the trait (Table 1). The genetic coefficient of variation $\left(\mathrm{CV}_{\mathrm{g}}\right)$ indicates the proportion of genetic variability among progenies in relation to 
the population mean and is a good indicator of the genetic potential of the populations (Ribeiro et al., 2009). $C V_{g}$ of the populations under evaluation varied in the range 2.79 to $10.20 \%$, which represents good genetic potential for crude fiber content in the environments studied (Table 1). Such values were close to the estimates obtained by Londero et al. (2006) (6.87 to 9.34\%).

The ratio between the largest and the smallest residual mean square was $<7$ (PimentelGomes, 1990), which makes it possible to combine the analysis of the experiments (Table 2). The majority of the effects were observed to be significant $(\mathrm{P}<0.01)$, except for parents and the parents by environment interaction. Thus, it was noted that the breeding methods presented differences in their efficiency to generate progenies, and in addition, variability among progenies within each method was detected, as well as progeny by environment interaction for all breeding methods. This provides evidence of the complexity of a breeding program aimed at the improvement of crude fiber of common beans as well as the importance of studies that identify the most efficient method for developing segregant populations for this trait.

Table 2. Summary of the combined analysis of variance for crude fiber content in grains of $F_{8}$ progenies obtained through three breeding methods evaluated in eleven environments.

\begin{tabular}{|c|c|c|c|c|}
\hline Source of variation & Degrees of freedom & Sum of squares & Mean square & $P$ value \\
\hline Environments (E) & 10 & 72.5980 & 7.2598 & 0.0000 \\
\hline Adjusted treatments $(\mathrm{T})$ & 48 & 24.3036 & 0.5063 & 0.0000 \\
\hline Bulk within $\mathrm{F}_{2}\left(\mathrm{~F}_{2: 8}\right)$ & 14 & 4.5819 & 0.3273 & 0.0000 \\
\hline Bulk-population $\left(\mathrm{F}_{5.8}\right)$ & 14 & 8.9771 & 0.6412 & 0.0000 \\
\hline $\operatorname{SSD}\left(\mathrm{F}_{5.8}\right)$ & 14 & 3.8731 & 0.2766 & 0.0000 \\
\hline Checks (Chk.) & 1 & 2.9390 & 2.9390 & 0.0000 \\
\hline Parents $(\mathrm{P})$ & 1 & 0.2116 & 0.2116 & 0.1330 \\
\hline Methods (M) & 2 & 0.8138 & 0.4069 & 0.0140 \\
\hline Chk. $v s \mathrm{P} v s \mathrm{M}$ & 2 & 2.9070 & 1.4535 & 0.0000 \\
\hline TxE & 480 & 128.4480 & 0.2676 & 0.0000 \\
\hline Bulk within $\mathrm{F}_{2}\left(\mathrm{~F}_{2.8}\right) \times \mathrm{E}$ & 140 & 32.9625 & 0.2355 & 0.0000 \\
\hline Bulk-population $\left(\mathrm{F}_{5.8}\right) \times \mathrm{E}$ & 140 & 46.3336 & 0.3310 & 0.0000 \\
\hline $\operatorname{SSD}\left(\mathrm{F}_{5.8}\right) \times \mathrm{E}$ & 140 & 33.7049 & 0.2408 & 0.0000 \\
\hline Chk. $x$ E & 10 & 3.2484 & 0.3248 & 0.0000 \\
\hline $\mathrm{P} \times \mathrm{E}$ & 10 & 0.8150 & 0.0815 & 0.5600 \\
\hline $\mathrm{M} \times \mathrm{E}$ & 20 & 4.1259 & 0.2063 & 0.0000 \\
\hline Chk. $v s \mathrm{P} v s \mathrm{M} \times \mathrm{E}$ & 20 & 7.2578 & 0.3629 & 0.0000 \\
\hline Effective mean error & 396 & 37.0260 & 0.0935 & - \\
\hline Mean $(\%)$ & 4.85 & - & - & - \\
\hline Lattice relative efficiency (\%) & 106 & - & - & - \\
\hline
\end{tabular}

The small difference among averages of the progenies created using the three different methods reinforces the importance of attaining estimates of parameters that would permit the comparison of methods by means of the estimation of the genetic potential of these populations for crude fiber content (Table 3 ). The estimates of the genetic parameters and the significance of progeny effects within each method confirm the existence of variability for the trait in this population. Despite the occurrence of similar crude fiber content in both parental genotypes, favorable alleles present in each line were probably distinct, inducing variability into the population. It is worth noting that the initial contrast between the parents was determined through the acid extraction method and for the process of final evaluation of the progenies the acid-basic extraction method was used because it is an official, most realistic, and consistent method for estimating fiber content of a nutriment (AOAC, 1997). In spite of reports of a high correlation between fiber content estimated using both extraction methods (Londero et al., 2006), the contrast observed in the parent selection using acid extraction was not confirmed 
when the acid-base extraction was performed.

One of the factors that interferes the most with a breeder's work is the component of the genotype by environment interaction. The study of this interaction in relation to crude fiber content is of paramount importance for the process of developing new bean cultivars, which will be recommended according to their nutritional quality because this trait will be present in all recommended environments. If this is not so, the beans could be rejected in the seed market.

Upon consideration of all progenies regardless of the breeding method, the variance of the genotype by environment interaction was $422 \%\left(R_{i}\right)$ greater than the estimate of genetic variance $\hat{\sigma}_{g_{i}}^{2}$. For the progenies obtained through the bulk-population method, this estimate was $434 \%$ greater than the $\hat{\sigma}_{g_{i}}^{2}$; for the bulk within $\mathrm{F}_{2}$ method the estimate was $607 \%$ greater than the $\hat{\sigma}_{g_{i}}^{2}$, and for the SSD method, the estimate was $804 \%$ greater than the $\hat{\sigma}_{g_{i}}^{2}$. For progenies obtained using the bulk-population method, the proportion of the interaction $\left(P_{i}\right)$ corresponded to $23.5 \%$, followed by the bulk within $\mathrm{F}_{2}$ method with $33.0 \%$, and the SSD method with $43.6 \%$ (Table 3). It is notable that in progenies derived through SSD, the $P_{i}$ variation was almost twice as much as the value observed using the bulk-population method, as well as approximately one and a half times that observed using the bulk within $\mathrm{F}_{2}$ method. The explanation for this difference is mainly due to the magnitude of the genetic variation among progenies, which in the bulk-population method was more accentuated than in the other two methods. The progenies obtained through bulk-population were less influenced by the environment, a positive factor for the development of superior advanced strains for such grain quality traits, since in new cultivars with an aggregated value, too much variation in the trait may be a hindrance for the success of new cultivars.

Table 3. Estimates of averages and of phenotypic and genetic parameters for crude fiber content in grains of common bean $\mathrm{F}_{8}$ progenies for the three breeding methods evaluated in eleven environments.

\begin{tabular}{|c|c|c|c|c|}
\hline Methods & Bulk within F2 & Bulk-population & SSD & Mean \\
\hline$\hat{\sigma}_{g_{i}}^{2 a}$ & 0.01063 & 0.02490 & 0.00832 & 0.01876 \\
\hline$\hat{\sigma}_{p_{i}}^{a_{i}}$ & 0.01488 & 0.02915 & 0.01257 & 0.02301 \\
\hline 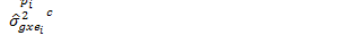 & 0.06452 & 0.10793 & 0.06693 & 0.07914 \\
\hline 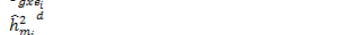 & 71.43 & 85.42 & 66.20 & 81.53 \\
\hline$S\left(h_{m}^{2}\right)_{i}^{e}$ & \pm 10.99 & \pm 5.61 & \pm 13.00 & \pm 3.99 \\
\hline$C V_{g}(\%) \mathrm{f}$ & 2.13 & 3.24 & 1.86 & 2.81 \\
\hline$C V_{s}^{g}(\%) \mathrm{g}$ & 6.32 & 6.27 & 6.26 & 6.28 \\
\hline$R_{i}^{{ }^{h}}{ }^{h}$ & 607 & 434 & 804 & 422 \\
\hline$P_{i}^{i}$ & 33.0 & 23.5 & 43.6 & - \\
\hline Mean (\%) & 4.84 & 4.87 & 4.89 & 4.87 \\
\hline Mean of the 5 selected progenies & 4.96 & 5.07 & 5.02 & - \\
\hline$S G_{i}(\%)^{j}$ & 1.83 & 3.37 & 1.72 & - \\
\hline
\end{tabular}

${ }^{\mathrm{a}}$ Genetic variance. ${ }^{\mathrm{b}}$ Phenotypic variance. ${ }^{\mathrm{c}}$ Variance of the genotype $\mathrm{x}$ environment interaction. ${ }^{\mathrm{d}}$ Mean heritability. ${ }^{\circ}$ Error associated to the heritability estimate. ${ }^{\mathrm{f}} \mathrm{Genetic}$ coefficient of variation. ${ }^{g}$ Experimental coefficient of variation.

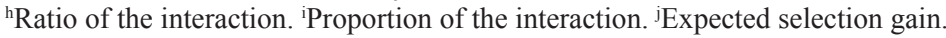

The mean heritability $\hat{h}_{m_{i}}^{2}$ for crude fiber content was $81.5 \%$ (Table 3 ). The bulk-population method led to the highest $\hat{h}_{m_{i}}^{2}$ estimate (85.4\%), followed by bulk within $\mathrm{F}_{2}(71.4 \%)$, and SSD $(66.2 \%)$, which is in accordance with the magnitude of the $\hat{\sigma}_{g_{i}}^{2}$ obtained in each method (Table 3). The error estimate associated with the $\widehat{h}_{m_{i}}^{2}$ for each breeding method was smallest in the bulk-population method $( \pm 5.61)$, followed by the bulk within $\mathrm{F}_{2}$ method $( \pm 10.99)$, and then the SSD method ( \pm 13.00$)$. Therefore, it was observed that the highest estimates of $\hat{h}_{m_{i}}^{2}$ had 
smaller associated errors, and SSD was the method with the least precision for the estimate of the $\hat{h}_{m_{i}}^{2}$ parameter, whereas bulk-population presented the greatest precision in relation to the other two methods under evaluation.

Considering that the expected gain with selection is a function of the $h^{2}$ in the generation in which the progenies are evaluated (Ramalho et al., 1993), the methods that presented the highest $h^{2}$ estimates are also the ones that yield the highest gain under selection. The bulkpopulation method presented the highest selection gain (3.37\%), followed by the bulk within $\mathrm{F}_{2}$ method (1.83\%), and the SSD method (1.72\%; Table 3$)$.

Upon selection of $10 \%$ of the total number of progenies under evaluation for crude fiber content, it was observed that the bulk-population method presented the highest percent of progenies (60\%) among the $P_{5+}$, followed by the SSD method (40\%) (Table 4). Considering the $P_{5-}$, the bulk within $\mathrm{F}_{2}$ method showed the highest percent $(60 \%)$, followed by the bulkpopulation method with $40 \%$. It was verified that the parental average was smaller than the mean of all progenies under evaluation and that the best parent surpassed only three progenies (two out of the bulk within $\mathrm{F}_{2}$ and one out of the bulk-population method), which indicates the occurrence of substantial transgressive segregation, probably generated by a genotypic complementarity between progenitors for the character under selection.

Table 4. Number of progenies amongst the five best and the five worst that surpass parental average or the average of the best parent and total sum of ranks of each method.

\begin{tabular}{lccccc}
\hline Methods & $P_{5+}$ & $P_{5-}$ & SPA & SHP & TSR \\
\hline Bulk within $\mathrm{F}_{2}\left(\mathrm{~F}_{2: 8}\right)$ & 0 & 3 & 15 & 13 & 325 \\
Bulk-population $\left(\mathrm{F}_{5: 8}\right)$ & 3 & 2 & 15 & 14 & 310 \\
SSD $\left(\mathrm{F}_{5: 8}\right)$ & 2 & 0 & 15 & 15 & 259 \\
\hline
\end{tabular}

$P_{5+}=$ Progenies among the five best $P_{5-}=$ progenies among the five worst; SPA = superior to parental average; SHP $=$ superior to the highest-average parent; TSR $=$ total sum of ranks.

In terms of the TSR, the SSD method exhibited the smallest estimate (259), followed by the bulk-population method (310), and the bulk within $\mathrm{F}_{2}$ method (325). From the previous results, it was expected that the bulk-population method would present the smallest value of TSR (Table 4). Nonetheless, upon analyzing the averages of progenies selected using the bulkpopulation method, they were observed to exhibit the greatest variation in ranks, with some progenies amongst the first ranks and others among the last ranks (Table 5). Such results can be explained by the great variability exhibited by the progenies selected through this method (Table 3 ), which contributed to the development of progenies with quite contrasting performances. In contrast, progenies selected using the SSD method showed the least variability since progenies with values closer to the overall average for the trait were obtained, i.e., without extreme values. However, for progenies selected using the bulk within $\mathrm{F}_{2}$ method, there was a preponderance of progenies with the worst values, which led to a high TSR value (Table 5).

When considering the genetic parameters that were estimated, the bulk-population method was superior to the other methods because it aggregates high variability among progenies with high average and greater stability (with less proportion of the interaction). The differences among the methods are basically related to the role of natural selection and/or losses originating from the sampling processes during the development of the segregant populations. 
Some traits, such as grain yield for example, suffer from interference of both factors, although other traits, such as those related to grain quality, are normally only affected by sampling variations because they are not related to adaptive advantages, which is the mode of action of natural selection.

\begin{tabular}{|c|c|c|c|}
\hline Method/progeny identification & Fiber content & Method/progeny identification & Fiber content \\
\hline 1. Bulk 1 & 5.30 & 22. Bulk D. $F_{2} 8$ & 4.84 \\
\hline 2. Bulk 2 & 5.13 & 23. SSD 11 & 4.83 \\
\hline 3. SSD 1 & 5.10 & 24. Bulk 8 & 4.82 \\
\hline 4. SSD 2 & 5.07 & 24. Bulk 9 & 4.82 \\
\hline 5. Perola & 5.03 & 24. Bulk 10 & 4.82 \\
\hline 6. Bulk D. $F_{2} 1$ & 5.02 & 25. Bulk D. $F_{2} 9$ & 4.81 \\
\hline 7. SSD 3 & 5.01 & 26. SSD 12 & 4.80 \\
\hline 8. Bulk 3 & 5.00 & 27. SSD 13 & 4.79 \\
\hline 9. Bulk D. F 2 & 4.99 & 28. Bulk D. F 10 & 4.78 \\
\hline 10. Bulk D. F 3 & 4.98 & 28. Bulk D. F 11 & 4.78 \\
\hline 11. SSD 4 & 4.97 & 29. Bulk 11 & 4.77 \\
\hline 11. Bulk D. F 4 & 4.97 & 30. Bulk 12 & 4.76 \\
\hline 12. SSD 5 & 4.96 & 31. SSD 14 & 4.75 \\
\hline 13. SSD 6 & 4.95 & 32. Bulk 13 & 4.73 \\
\hline 14. SSD 7 & 4.94 & 32. SSD 15 & 4.73 \\
\hline 15. Bulk D. F 5 & 4.92 & 33. Bulk D. $F_{2} 12$ & 4.72 \\
\hline 16. Bulk 4 & 4.91 & 34. Bulk 14 & 4.71 \\
\hline 17. Bulk 5 & 4.90 & 35. Bulk D. $F_{2} 13$ & 4.69 \\
\hline 18. Bulk D. F 6 & 4.89 & 36. CNFC 7829 & 4.68 \\
\hline 19. Bulk 6 & 4.87 & 37. Bulk D. $F_{2} 14$ & 4.65 \\
\hline 20. SSD 8 & 4.86 & 38. Bulk $15^{2}$ & 4.64 \\
\hline 21. Bulk D. F 7 & 4.85 & 39. Bulk D. $F_{2} 15$ & 4.61 \\
\hline 21. SSD 9 & 4.85 & 40. CNFC 7812 & 4.56 \\
\hline 22. SSD 10 & 4.84 & 41. BRS Estilo & 4.51 \\
\hline 22. Bulk 7 & 4.84 & - & - \\
\hline
\end{tabular}

Bulk D. $F_{2}=$ bulk within $F_{2}$ families.

In regards to the SSD method, one hypothesis for the low variability of progeny averages could be the effect of the loss of alleles due to sampling, which is greater with this method and jeopardizes the maintenance of genetic gains over time. According to Ramalho et al. (2012), when a segregant population is developed in accordance with the SSD method, and therefore only one seed is kept per plant, only a part of the within plant variance is explored because $50 \%$ of the additive genetic variation among plants exists in the $\mathrm{F}_{2}$ generation, whereas $50 \%$ is hidden in heterozygotes, which will be liberated gradually through autogamous reproduction.

Other researchers have also obtained results indicating a reduction in genetic variability when utilizing the SSD method, especially due to small sample size and/or deficient sampling in segregant populations. In soybean breeding, Martin et al. (1978) reported that due to low seedling emergence and the presence of sterile plants, approximately $15 \%$ of the population was lost during each cycle of SSD. Mehta and Zaveri (2000) evaluated the magnitude of plant losses in generations of segregant populations (from $\mathrm{F}_{2}$ through $\mathrm{F}_{5}$ ) in cowpea (Vigna unguiculata $\mathrm{L}$.) and concluded that there was a $15 \%$ average reduction in population size over those generations for the four populations studied. Such fairly high plant losses may alter gene and genotypic frequencies in the population. Thus, genotypes present in a population created using the SSD method may not represent an unbiased sample of the original population.

Fouilloux and Bannerot (1988), utilizing the SSD method with common beans, ob- 
served that even under good climatic conditions and normal plant densities, plant losses of 10 to $20 \%$ occurred in subsequent generations. If plant loss of $10 \%$ were considered for each generation, after four generations, $35 \%$ reduction in population size would be expected.

Losses due to sampling have also been reported for the bulk-population method and are considered a hindrance of the method. Nevertheless, Fouilloux and Bannerot (1988) state that loss of lines does not necessarily lead to a corresponding reduction in genetic variability because the loss of individuals $/ \mathrm{F}_{2}$ lines due to sampling can be compensated by the liberation of variability since $\mathrm{F}_{2}$ individuals may be highly heterozygous. Muehlbauer et al. (1981) dem-

onstrated that in an $\mathrm{F}_{6}$ generation, $25 \%$ of the variability present is due to released variability within the line. Thus, such losses would not be drastic for the bulk-population method given a representative population and not necessarily large, as reported by Silva (2009) using a simulation. In this study, the author concluded that a population comprised of 2000 individuals, as is normally used in plant breeding programs, represents a good sample.

The superiority of the bulk-population method over the SSD method and other methods for conducting common bean segregant populations was demonstrated by Fouilloux and Bannerot (1988) and Raposo et al. (2000). Comparisons of breeding methods have been performed for other traits besides grain yield, with results always confirming the superiority of the bulk-population method. In research that evaluated the potential of biologic nitrogen fixation of segregant progenies, the bulk-population method was superior to SSD (Pereira and Braidotti, 2001). Silva et al. (2008), evaluating the genetic potential of segregant populations created using the breeding methods of bulk-population, bulk within $\mathrm{F}_{2}$ and SSD for grain bean protein content, concluded that enough genetic variability exists for selection and that the bulk-population method is more efficient in generating a greater number of progenies with superior averages.

In accordance with the research cited here in, the present study demonstrated that bulk-population was the most efficient method for the development of superior progenies for crude fiber content. Another positive aspect of the method is that its utilization is simple, inexpensive, and straightforward, thus contributing further to the recommendation of using the bulk-population method in breeding programs aimed at improving crude fiber in common beans. In light of the results presented here, it is expected that the effect of losses by sampling using the SSD method contributes to the development of progenies with reduced genetic potential ( $h^{2}$ and genetic gain), as well as being subjected to a greater degree of environmental interactions. Therefore, the fact that SSD allows for sampling with some restriction of variability, the method has hindered the performance of its derived progenies, especially when compared with progenies originating from the bulk-population method.

In conclusion, the bulk-population method leads to the development of segregant populations with higher estimates of genetic variance, $h^{2}$, average, and gain than the SSD and bulk within $\mathrm{F}_{2}$ methods when selecting for crude fiber content. Progenies developed through the bulk-population method presented less interaction with the environment than progenies obtained through the SSD and bulk within $\mathrm{F}_{2}$ methods.

\section{ACKNOWLEDGMENTS}

The authors are indebted to Embrapa Arroz e Feijão and Universidade Federal de Goiás for the use of their facilities and overall support of this research, Coordenação de Aperfeiçoamento de Pessoal de Nível Superior (CAPES), Graduate Program of Plant Breeding and 
Genetics, and CNPq for the concession of Technology Development and Innovation Extension assistantship to P.G.S. Melo, H.S. Pereira, and L.C. Melo

\section{REFERENCES}

Acevedo E and Bressani R (1990). Contenido de fibra dietetica y digestibilidad del nitrogeno en alimentos centroamericanos: Guatemala. Arch. Latinoam. Nutr. 40: 439-451.

Antunes PL, Bilhalva AB, Elias MC and Soares GJD (1995). Valor nutricional de feijão (Phaseolus vulgaris L.), cultivares Rico 23, Carioca, Piratâ-1 e Rosinha-G2. Rev. Bras. Agro. 1: 12-18.

AOAC International (1997). Official methods of analysis of AOAC International, 16th edn. Association of Official Analytical Chemists, Washington.

Bach S, Yada RY, Bizimungu B and Sullivan JA (2012). Genotype by environment interaction effects on fibre components in potato (Solanum tuberosum L.). Euphytica 187: 77-86.

Carbonell SAM, Azevedo Filho JA, Dias LAS, Garcia AAF, et al. (2004). Common bean cultivars and lines interactions with environments. Sci. Agric. 61: 169-177.

Chaves LJ (2001). Interação de genótipos com ambientes. In: Recursos genéticos e melhoramento-plantas (Nass LL, Valois ACC, Melo IS and Valadares-Inglis MC, eds.). Fundação MT, Rondonópolis, 673-713.

Costa NMB (2003). Alimentos: componentes nutricionais e funcionais. In: Biotecnologia e nutrição: saiba como o DNA pode enriquecer os alimentos (Costa NMB and Borém A, eds.). Nobel, São Paulo, 32-69.

Fouilloux G and Bannerot H (1988). Selection methods in the common bean (Phaseolus vulgaris). In: Genetic resources of Phaseolus beans (Gepts P, eds.). Kluwer Academic Publishers, Dordrecht, 503-541.

Geil PB and Anderson JW (1994). Nutrition and health implications of dry beans: a review. J. Am. Coll. Nutr. 13: 549-558.

Guerra NB, David PRBS, Melo DD, Vasconcelos ABB, et al. (2004). Modificações do método gravimétrico não enzimático para determinar fibra alimentar solúvel e insolúvel em frutos. Rev. Nutr. 17: 45-52.

Hilton JW, Atkinson JL and Slinger SJ (1983). Effect of increased dietary fiber on the growth of rainbow trout (Salmo gardneri). Can. J. Fish. Aquat. Sci. 40: 81-85.

Hughes JS (1991). Potential contribution of dry bean dietary fiber to health. Food Technol. 45: 122-146.

Kathleen ML (1998). Krause: alimentos, nutrição e dietoterapia. Roca, São Paulo.

Larbier M and Leclercq B (1992). Nutrition and Feeding of Poultry. Nottingham University Press, Nottingham.

Londero PMG, Ribeiro ND, Cargnelutti Filho A, Rodrigues JA, et al (2006). Herdabilidade dos teores de fibra alimentar e rendimento de grãos em populações de feijoeiro. Pesqui. Agropecu. Bras. 41: 51-58.

Londero PMG, Ribeiro ND, Jost E, Maziero SM, et al. (2009). Genética dos teores de fibra insolúvel e solúvel em grãos de feijão. Ceres 56: 150-155.

Martin RJ, Wilcox JR and Laviolette FA (1978). Variability in soybean progenies developed by single seed descent at two plant populations. Crop Sci. 18: 359-362.

Mehta DR and Zaveri PP (2000). Plant loss during ssd scheme in cowpea. Agric. Sci. Digest. 20: 24-26.

Melo LC, Melo PGS, Faria LC, Cabrera Diaz JL, et al. (2007). Interação com ambientes e estabilidade de genótipos de feijoeiro-comum na região centro-sul do Brasil. Pesqui. Agropecu. Bras. 42: 715-723.

Moore MA, Park CB and Tsuda H (1998). Soluble and insoluble fiber influences on cancer development. Crit. Rev. Oncol. Hematol. 27: 229-242.

Muehlbauer FJ, Burnell DG, Bogyo TP and Bogyo MT (1981). Simulated comparisons of single seed descent and bulk population breeding methods. Crop Sci. 21: 572-577.

Oliveira GV, Carneiro PCS, Carneiro JES and Cruz CD (2006). Adaptabilidade e estabilidade de linhagens de feijoeiro comum em Minas Gerais. Pesqui. Agropecu. Bras. 41: 257-265.

Pereira HS, Melo LC, Faria LC, Del Peloso MJ, et al. (2009). Adaptabilidade e estabilidade de genótipos de feijoeirocomum com grão na região central do Brasil. Pesqui. Agropecu. Bras. 44: 29-37.

Pereira HS, Melo LC, Faria LC, Del Peloso MJ, et al. (2010). Indicação de cultivares de feijoeiro-comum baseada na avaliação conjunta de diferentes épocas de semeadura. Pesqui. Agropecu. Bras. 45: 571-578.

Pereira PAA and Braidotti W (2001). Comparação de métodos de melhoramento de feijão (Phaseolus vulgaris) para o incremento da fixação simbiótica do nitrogênio. Pesqui. Agropecu. Trop. 31: 15-21.

Pimentel-Gomes F (1990). Curso de estatística experimental. 13th edn. Nobel, São Paulo.

Ramalho MAP, Santos JB and Zimmermann MJO (1993). Genética quantitativa em plantas autógamas: aplicações ao melhoramento do feijoeiro. Universidade Federal de Goiás, Goiânia.

Ramalho MAP, Abreu AFB and Santos PSJ (1998). Interações genótipos x épocas de semeaduras, anos e locais na avaliação de cultivares de feijão nas regiões sul e alto Paranaíba em Minas Gerais. Cienc. Agrotec. 22: 176-181.

Genetics and Molecular Research 14 (2): 5763-5774 (2015) 
Ramalho MAP, Abreu AFB and Santos PSJ (2001). Melhoramento de espécies autógamas. In: Recursos genéticos e melhoramento: plantas (Nass LL, Valois ACC, Melo IS and Valadares-Inglis MC, eds.). Fundação MT, Rondonópolis, 201-230.

Ramalho MAP, Abreu AFB, Santos JB and Nunes JAR (2012). Aplicações da genética quantitativa no melhoramento de plantas autógamas. Editora UFLA, Lavras.

Raposo FV, Ramalho MAP and Abreu AFB (2000). Comparação de métodos de condução de populações segregantes de feijoeiro. Pesqui. Agropecu. Bras. 35: 1991-1997.

Ribeiro EH, Pereira MG, Coelho KS and Freitas Júnior SP (2009). Estimativas de parâmetros genéticos e seleção de linhagens endogâmicas recombinantes de feijoeiro comum (Phaseolus vulgaris L.). Rev. Ceres 56: 580-590.

Ribeiro ND, Londero PMG, Hoffmann Junior L, Poersch NL, et al. (2005). Dissimilaridade genética para proteína e fibra em grãos de feijão dos grupos preto e de cor. Rev. Bras. Agro. 11: 167-173.

Silva ACF, Melo PGS, Melo LC, Bassinello PZ, et al. (2013). Eficiência de métodos de melhoramento para teor de fibra e produtividade de grãos em progênies de feijoeiro comum. Bragantia 72: 326-331.

Silva JW (2009). Employment of simulation in selecting the number of individuals in the method "bulk" in the plant breeding autogamous. Doctoral thesis, Universidade Federal de Lavras, Lavras.

Silva GFO, Melo PGS, Melo LC, Bassinello PZ, et al. (2008). Efficiency of methods for conducting segregating populations in the breeding of common beans for protein quality. Crop Breed. Appl. Biotechnol. 8: 149-154.

TACO (Brazilian Table of Food Composition). Available at [http://www.unicamp.br/nepa/taco]. Accessed June 13, 2013.

Torga PP, Melo PGS, Pereira HS, Faria LC, et al. (2013). Interaction of common beans cultivars of the black group with years, locations and sowing seasons. Euphytica 189: 239-248.

Vello NA and Vencovsky R (1974). Variâncias associadas às estimativas de variâncias genéticas e coeficientes de herdabilidade. Relat. Cient. Inst. Genet. 8: 238-248.

Vencovsky R and Barriga P (1992). Genética biométrica no fitomelhoramento. Sociedade Brasileira de Genética, Ribeirão Preto.

Vieira C, Borém A, Ramalho MAP and Carneiro JES (2005). Melhoramento do feijão. In: Melhoramento de espécies cultivadas (Borém A, eds.). Editora UFV, Viçosa, 301-391. 